\title{
The Study of Cephalic Index in North Indian Population
}

\author{
Estudio de Índice Cefálico en una Población del Norte de India
}

Seema* \& Poonam Verma*

SEEMA \& VERMA, P. The study of cephalic index in north Indian popuation. Int. J. Morphol., 34(2):660-664, 2016.

SUMMARY: Cephalic index (CI) and head shape are greatly affected by geographical, sex, age and racial factors. Such data is of great medico legal and forensic importance which indicates that cephalic index can be used as marker of ethnicity. There is less published literature about cephalic index of Punjab population. Hence, we undertook this study to document the cephalometric characteristics and gender differences in cephalic index of Punjabi community. Head length, head breadth and CI were determined for 500 medical students (17-23 years) of Punjab. The mean cephalic index for males was 80.52 and for females 84.32 which was statistically significant. On comparison with the existing literature the Punjabi community can be categorized as Brachycephalic/ Hyperbrachicephalic. This is of immense value in forensic science for facial reconstruction of disputed identity, orthodontics, different oral \& maxillofacial surgery or craniofacial surgery, paleoanthropology and phylogeography.

KEY WORDS: Cephalic index; Head-length; Head-breadth; Brachicephalic.

\section{INTRODUCTION}

The name cephalometry is the morphological study of all the structures present in a human head (Grau et al., 2001). On basis of cephalic index head shapes are grouped in four international categories including dolichocephalic, brachycephalic, mesocephalic and hyperbrachycephalic (Williams et al., 1995). Anthropometric measurements especially craniofacial measurements are important for determining various head and face shapes. This helps in better understanding the frequency distribution of human morphologies and comparison of different races. Comparison of changes between parents, offspring and siblings can give a clue to genetic transmission of inherited character (Shah \& Jadav, 2004). Also standardized cephalometric records help diagnostic comparison between patients and the normal population (Rabey, 1971) and are useful in pediatrics, forensic medicine, plastic surgery and oral surgery dentistry (Golalipour, 2006a). It is also reported that persons having Alpert's syndrome are hyperbrachycephalic (Cohen \& Kreiborg, 1994). Craniometry is also employed in the measurement of cranial features in order to classify people according to race, criminal temperament, intelligence, and so forth. The underlying assumption of craniometry is that skull size and shape determine brain size (Morant \& Woo, 1932).
Comparison between cephalic indices and the head shapes with race, age and sex is important, which are valuable for treatment monitoring and prediction of orthodontic treatment and the knowledge is valuable in plastic and reconstructive surgeries concerned with craniofacial deformities (Williams et al.). The relevant data on cephalic index of a population is necessary for the preparation of cranial remodeling band, or helmet as durable medical equipment, necessary for positional head deformities associated with premature birth and in infants with synostotic plagiocephaly to correct continued asymmetry following surgery or to correct without surgery. The cephalometric study is also important in forensic science for the facial reconstruction of disputed identity.

\section{MATERIAL AND METHOD}

This present research was done on 500 medical students (250 males and 250 females). Medical students were selected because of the easy availability. The age of the students ranged from 17 to 23 years in a normal healthy state. Instruments used in the study were manual spreading 
calipers and pencil. Students were informed about the study design, its benefits and privacy of the data collected. Consent form was given to each student and consent was taken. Students were asked to sit in a relaxed state, straight and looking forward. The method used for assessing the cephalic index is Hrdlicka's method (Stewart, 1952). The glabella (g), inion (I) and euryon (eu) are the landmarks which were marked.

The anatomical landmarks were defined as follows:

Glabella: A point above the nasal root between the eyebrows and intersected by mid sagittal plane.

Inion: The distal most point placed on the external occipital protuberance in the mid sagittal plane.

Euryon: The lateral most point placed on the side of the head.

The head length was measured with a spreading caliper from glabella to Inion. Head breadth was measured as the maximum transverse diameter between the two euryons using a spreading caliper. The cephalic index was determined on the basis of international anatomical descriptive (Williams et al.).

\section{Cephalic Index $=$ Head breadth $/$ Head length $X 100$}

Depending upon this index, the types of head shapes were followed as as shown in Table I.

Table I. All types of heads according to Hrdlicka's method.

\begin{tabular}{llll}
\hline Sr & Head shape & Cephalic & Range \\
\hline 1 & Dolicocephalic & --- & $<74.9$ \\
2 & Mesocephalic & $75<$ CI & $<79.9$ \\
3 & Brachycephalic & $80<$ CI & $<84.9$ \\
4 & Hperbrachycephalic & $85<$ CI $<89.9$ & CI $<89.9$ \\
\hline
\end{tabular}

\section{RESULTS}

All measurements were expressed in centimeters. The data represents the values of head length, head breadth and cephalic index of all subjects. The results were computed and analyzed statistically as shown in Tables II to V. The minimum cephalic index is found to be 71.02 and maximum cephalic index is found to be 91.56 . The mean cephalic index was 85.53 . The mean cephalic index for male was 80.52 and for female it was 84.32 .
In males head length ranged from $14.01 \mathrm{~cm}$ to 22.0 $\mathrm{cm}$ with mean of $18.85 \mathrm{~cm}$ and head breadth from $12.01 \mathrm{~cm}$ to $18.00 \mathrm{~cm}$ with mean of $15.80 \mathrm{~cm}$. In females head length ranged from $14.01 \mathrm{~cm}$ to $22.00 \mathrm{~cm}$ with mean of $17.88 \mathrm{~cm}$ and head breadth ranged from $12.01 \mathrm{~cm}$ to $18.00 \mathrm{~cm}$ with a mean of $14.78 \mathrm{~cm}$.

Table II. The incidence of cephalic index.

\begin{tabular}{cc}
\hline Cephalic Index & No observed \\
\hline $71.01-72.00$ & 3 \\
$72.01-73.00$ & 7 \\
$73.01-74.00$ & 3 \\
$74.01-75.00$ & 9 \\
$75.01-76.00$ & 21 \\
$76.01-77.00$ & 9 \\
$77.01-78.00$ & 11 \\
$78.01-79.00$ & 47 \\
$79.01-80.00$ & 15 \\
$80.01-81.00$ & 69 \\
$81.01-82.00$ & 31 \\
$82.01-83.00$ & 60 \\
$83.01-84.00$ & 24 \\
$84.01-85.00$ & 96 \\
$85.01-86.00$ & 8 \\
$86.01-87.00$ & 12 \\
$87.01-88.00$ & 42 \\
$88.01-89.00$ & 9 \\
$89.01-90.00$ & 8 \\
$90.01-91.00$ & 1 \\
$91.01-92.00$ & 3 \\
\hline
\end{tabular}

Table III. Sex distribution of cephalic index.

\begin{tabular}{lcc}
\hline Cephalic Index & Male & Female \\
\hline $71.01-72.00$ & 2 & 9 \\
$72.01-73.00$ & 5 & 13 \\
$73.01-74.00$ & 5 & 10 \\
$74.01-75.00$ & 2 & 6 \\
$75.01-76.00$ & 4 & 8 \\
$76.01-77.00$ & 6 & 7 \\
$77.01-78.00$ & 3 & 7 \\
$78.01-79.00$ & 38 & 16 \\
$79.01-80.00$ & 6 & 5 \\
$80.01-81.00$ & 48 & 24 \\
$81.01-82.00$ & 25 & 21 \\
$82.01-83.00$ & 13 & 38 \\
$83.01-84.00$ & 30 & 7 \\
$84.01-85.00$ & 32 & 27 \\
$85.01-86.00$ & 6 & 6 \\
$86.01-87.00$ & 6 & 14 \\
$87.01-88.00$ & 5 & 9 \\
$88.01-89.00$ & 6 & 7 \\
$89.01-90.00$ & 3 & 7 \\
$90.01-91.00$ & 2 & 5 \\
$91.01-92.00$ & 3 & 4 \\
\hline
\end{tabular}


Table IV. Head length $(\mathrm{cm})$ in males and females.

\begin{tabular}{cccc}
\hline $\begin{array}{c}\text { Males } \\
\text { Head length }(\mathbf{c m})\end{array}$ & $\mathbf{n}$ & $\begin{array}{c}\text { Females } \\
\text { Head length }(\mathbf{c m})\end{array}$ & $\mathbf{n}$ \\
\hline $14.01-15.00$ & 9 & $14.01-15.00$ & 9 \\
$15.01-16.00$ & 6 & $15.01-16.00$ & 8 \\
$16.01-17.00$ & 4 & $16.01-17.00$ & 33 \\
$17.01-18.00$ & 74 & $17.01-18.00$ & 80 \\
$18.01-19.00$ & 46 & $18.01-19.01$ & 65 \\
$19.01-20.00$ & 50 & $19.01-20.00$ & 27 \\
$20.01-21.00$ & 48 & $20.01-21.00$ & 19 \\
$21.01-22.00$ & 13 & $21.01-22$ & 9 \\
\hline
\end{tabular}

Table V. Head breadth $(\mathrm{cm})$ in males and females.

\begin{tabular}{cccc}
\hline $\begin{array}{c}\text { Males } \\
\text { Head bread th (cm) }\end{array}$ & $\mathbf{n}$ & $\begin{array}{c}\text { Females } \\
\text { Head breadth }(\mathbf{c m})\end{array}$ & $\mathbf{n}$ \\
\hline $12.01-13.00$ & 4 & $12.01-13.00$ & 35 \\
$13.01-14.00$ & 31 & $13.01-14.00$ & 41 \\
$14.01-15.00$ & 71 & $14.01-15.00$ & 71 \\
$15.01-16.00$ & 82 & $15.01-16.00$ & 56 \\
$16.01-17.00$ & 29 & $16.01-17.00$ & 42 \\
$17.01-18.00$ & 33 & $17.01-18.00$ & 5 \\
\hline
\end{tabular}

\section{DISCUSSION}

The effects of given environment represents the interaction of the genotype of the population being studied with the environment (Jordaan, 1976) or can also change from one generation to the other (Heravi \& Zieaee, 2002). Kasai et al. (1993) reported that dietary habits have been also shown to influence the craniofacial form of a population.

A large number of studies exist on the adult cephalic index of Caucasians, Japanese and Australian (Kasai et al.), Nigerian (Eroje et al., 2010), Iran (Vojdani et al., 2009; Golalipour, 2006b; Abolhasanzadeh \& Farahani, 2003), and Indian population such as Kvangaja (Basu, 1963), Bhils and Barelias (Bhargava \& Kher, 1960, 1961), Gujarat races (Shah \& Jadav). In the present study mean head lengths in males shows higher value $(18.85 \mathrm{~cm})$ than Gujarati females (16.5 $\mathrm{cm})$. Also the head breadth in both males and females when compared to Gujarati was almost similar. In the present study mean cephalic index of males was 80.52 . This finding was slightly higher than Bhils study with 76.98 (Bhargava \& Kher, 1960). But approximately equal Barelas with 79.80 (Bhargava \& Kher, 1961) and Gujarati males with 80.42 (Shah \& Jadhav) of Indian group. Also when compared with other groups such as European (81.19), North of Europe (79.72) (Garcia \& Lips., 1986a), Chile (81.51) (Garcia \& Lips, 1986b), Iran 80.4 (Golalipour et al., 2007), south of Iran (82.4) (Vojdani et al.), Ijaw (80.98) and Igbo (79.04) tribes community (Oladipo \& Olotu, 2006), Baysela state, Nigeria (73.68) (Eroje et al.) it was lower.

The cephalic index of Punjabi females in present study was 84.32. This finding was lower than Nakashima (1986) study with 87, Golalipour (2006a) study on native Fars group with 85 , Turkman group 82.8 in North of Iran (Golalipour, 2006b), Shah \& Jadhav from India with 81.20. But higher than Abolhasanzadeh \& Farahani study in Tehrancenter of Iran with 75, and Igbo (76.83) tribes community (Oladipo \& Oluto), Baysela state, Nigeria with 72.24 (Eroje et al.). From the present study Punjab zone people can be called brachicephalic or hyperbrachicephalic (Steward, 1936). It is similar to study done on Tehran - Iran (36.6\%) (Abolhasanzadeh \& Farahani). Brachycephalization and secular change were also seen in head length in Japanese population (Kondo et al., 1999). Comparing previous records of cephalic index with recent work proves tendency towards "brachycephalisation" - evidence of continuous growth of brain more in the lateral direction (Shah \& Jadhav). Also, in tropical zones head form is longer (dolichocephalic), but in temperate zones the head form is more round (mesocephalic or brachycephalic) (Bharati et al., 2001). Since India is partly in temperate and tropical zone, the present classification shows tendency to brachycephalization from dolicocephalic. With the help of the above statistics, the sex as well as race of the deceased can be determined accurately with the head measurement. This knowledge can be of immense importance to anthropologists as well as forensic science experts.

Table VI. Comparative data on cephalic index of various populations.

\begin{tabular}{lcc}
\hline Country/People & References & Cephalic index \\
\hline Kvangaja race & Basu (1963) & 79.5 \\
Bhils race & Bhargava \& Kher (1960) & 76.98 \\
Barelias & Bhargava \& Kher (1961) & 79.8 \\
Gujarat & Shah \& Jadhav (2004) & 80.81 \\
Ijaw (Male / Female) & Oladipo \& Oluto (2006) & $80.81 / 78.24$ \\
Mumbai (Male / Female) & Khair et al. $(2011)$ & $94.41 / 82.16$ \\
Indians (Male / Female) & Yagain et al. $(2012)$ & $77.92 / 80.85$ \\
Present study (Male / Female) & Seema \& Verma (2016) & $80.52 / 84.32$ \\
\hline
\end{tabular}




\section{CONCLUSIONS}

The results of the present study showed that Punjab population can be classified as Brachycephalic / Hyperbrachicephalic. There was a significant gender difference in the cephalic index. Since there is no published data on cephalic index of Punjabis this data can be a major contribution to the anthropology and forensic science.

SEEMA \& VERMA, P. Estudio de índice cefálico en una población del norte de India. Int. J. Morphol., 34(2):660-664, 2016.

RESUMEN: El índice cefálico (IC) y la forma de la cabeza se ven afectados en gran medida por las regiones geográficas, el sexo, la edad y los factores raciales. Este tipo de dato son de gran importancia legal y forense dado que el IC puede ser utilizado como marcador de la etnia. Hay escasa literatura publicada sobre el IC de la población de Punjab. Por lo tanto, se realizó este estudio para documentar las características cefalométricas y las diferencias de sexo en el IC de una comunidad Punjabi. La longitud y ancho la cabeza, junto al IC, fueron determinados en 500 estudiantes de medicina (17-23 años) de Punjab. El IC medio para los hombres fue de 80,52 y para las mujeres 84,32 , lo que fue estadísticamente significativo. En comparación con la literatura existente, la comunidad Punjab puede ser categorizada como braquicefálica/ hiperbraquicefálica. Esta información es de importancia para las ciencias forenses en relación a la reconstrucción facial con fines de identificación, como así también para la cirugía oral, maxilofacial, craneofacial, la paleoantropología y la filogeografía.

PALABRAS CLAVE: Índice cefálico; Longitud de la cabeza; Ancho de la cabeza; Braquiocefalia.

\section{REFERENCES}

Abolhasanzadeh, A. \& Farahani, M. R. Standard international classification of head shapes of 22-24 years old in Tehran. $J$. Res. Med, 26:281-5, 2003.

Basu, A. Anthropometry of the kayasthas of Bengal. J. Anat. Soc. India, 3:20-5, 1963.

Bharati, S.; Som, S.; Bharati, R. \& Vasulu, T. S. Climate and head form in India. Am. J. Hum. Biol, 13(5):626-34, 2001.

Bhargava, I. \& Kher, G. A. A comparative anthropometric study of Bhils and Barelas of Central India. J. Anat. Soc. India, 10:2633, 1961.

Bhargava, I. \& Kher, G. A. An anthropometric study of Central India Bhils of Dhar district of Madhya Pradesh. J. Anat. Soc. India, 9:14-9, 1960.
Cohen, M. M. Jr. \& Kreiborg, S. Cranial size and configuration in the Apert syndrome. J. Craniofac. Genet. Dev. Biol., 14(3):153-62, 1994.

Eroje, M. A.; Fawehinmi, H. B.; Jaja, B. N. \& Yaakor, L. Cephalic index of Ogbia tribe of Bayesla state. Int. J. Morphol., 28(2):389-92, 2010.

García, H. F. \& Lips, M. W. Contribución al estudio del índice cefálico en chilenos. An. Anat. Norm., 4:120-3, 1986b.

García, H. F. \& Lips, M. W. Variaciones del índice cefálico en chilenos según ascendencia. An. Anat. Norm., 4:117-9, 1986a.

Golalipour, M. J. The effect of ethnic factor on cephalic index in 17-20 years old females of North of Iran. Int. J. Morphol., 24(3):319-22, 2006a.

Golalipour, M. J. The variation of head shapes in 17-20 years old native Fars male in Gorgan-North of Iran. Int. J. Morphol., 24(2):187-90, 2006b.

Golalipour, M. J.; Jahanshahi, M. \& Haidari, K. Morphological evaluation of head in Turkman males in Gorgan-North of Iran. Int. J. Morphol, 25(1):99-102, 2007.

Grau, V.; Alcañiz, M.; Juan, M. C.; Monserrat, C. \& Knoll, C. Automatic localization of cephalometric Landmarks. $J$. Biomed. Inform., 34(3):146-56, 2001.

Heravi, F. \& Zieaee, H. Assessing the importance of cephalic and facial indices in a group of 12 years old boys in Mashhad. Beheshti Univ. Dent. J., 20:119-24, 2002.

Jordaan, H. V. Neonatal and maternal cranial form. S. Afr. Med. J., 50(52):2064-8, 1976.

Kasai, K.; Richards, L. C. \& Brown, T. Comparative study of craniofacial morphology in Japanese and Australian aboriginal populations. Hum. Biol., 65(5):821-34, 1993.

Khair, S.; Bhandari, D. \& Wavhal, S. Study of cephalic index among the students of Mumbai Region. Indian J. App. Res., 3(11):64-6, 2011.

Kondo, S.; Wakatsuki, E. \& Shibagaki, H. A somatometric study of the head and face in Japanese adolescents. Okajimas Folia Anat. Jpn., 76(4):179-85, 1999.

Morant, G. M. \& Woo, T. L. A preliminary classification of Indian and Asiatic races. Biometrika, 24:108-34, 1932.

Nakashima, T. Brachycephalization in the head form of school girls in North Kyushu. J. UOEH, 8(4):411-4, 1986.

Oladipo, G. S. \& Olotu, J. Anthropometric comparison of cephalic indices between the Ijaw and Igbo tribes. Glob. J. Pure Appl. Sci., 12(1):137-8, 2006. 
Rabey, G. Craniofacial morphanalysis. Proc. R. Soc. Med., 64(2):103-11, 1971.

Shah, G. V. \& Jadhav, H. R. The study of CI in students of Gujarat. J. Anat. Soc. India, 53(1):25-6, 2004.

Stewart, T. D. Anthropometry. Anthropometric nomenclature. I. The cephalic (lengtm-breadth) index. Am. J. Anthropol., 22(1):97-140, 1936.

Stewart, T. D. Hrdlicka's Practical Anthropometry. 4th ed. Philadelphia, The Wistar Institute of Anatomy and Biology, 1952. pp.87-9.

Vojdani, Z.; Bahmanpour, S.; Momeni, S.; Vasaghi, A.; Yazdizadeh, A.; Karamifar, A.; Najafifar, A.; Setoodehmaram, S. \& Mokhtar, A. Cephalometry in 14-18 years old girls and boys of Shiraz-Iran High School. Int. J. Morphol., 27(1):101-4, 2009.

Williams, P.; Dyson, M.; Dussak, J. E.; Bannister, L. H.; Berry, M. M.; Collins, P. \& Ferguson, M. W. J. Gray's anatomy. In: Skeletal system. $38^{\text {th }}$ ed. London, Elbs with Churchil Livingston, 1995. pp.607-12.

Yagain, V. K.; Pai, S. R.; Kalthur, S. G.; Chethan, P. \& Hemalatha, I. Study of cephalic index in Indian students. Int. J. Morphol., 30(1):125-9, 2012.
Correspondence to:

Dr. Seema

Professor

Department of Anatomy

Sri Guru Ram Das Institute of Medical Sciences and

Research

Vallah

INDIA

Email: drseema16@gmail.com

Received: 03-11-2015

Accepted: 29-02-2016 